\title{
E. S. BEESLY AND KARL MARX
}

\author{
(continued from previous issue)
}

\section{IV}

Beesly was not only friendly with Marx, but was well acquainted with his circle. He knew Lafargue, he got to know Engels, and there were mutual acquaintances, such as Eugene Oswald. ${ }^{1}$ Among workmen, he was not only the friend of Odger, Applegarth and Lucraft, but was on close terms with such working-class confidants of Marx as Jung and Eccarius, and to a lesser extent with Dupont. ${ }^{2}$ In the sixties he was a familiar figure, not only in the offices of the Carpenters and Joiners, the London Trades Council or the Bee-Hive, but was also at home in the "Golden Ball" where the most radical of London's workmen talked with continental revolutionaries over a clay pipe and a pot of beer. Here one could get the flavour of European proletarian politics: that other "World of Labour" in whose ideals Beesly was as deeply interested as he was in those of English trades unionism. Indeed, for many years he expressed his desire for the amalgamation of trade unionism - with its implicit recognition of the priority of social questions -, and proletarian republicanism - with its generous enthusiasm and its larger view. When trade unionism had faced its supreme crisis at the time of the Sheffield outrages, he had boldly defended it before public opinion; it was in the same spirit that he now joined Marx in the defence of workingmen's Paris and the Commune:

Although Beesly bore the main burden of providing English working-class readers with an interpretation of events in Paris, the other Positivists - either in public or in private - joined with him in the defence of the Commune. Equally with him they saw it as a climax in the history of the class struggle. They were not blind to the patriotic,

1 Oswald, E., Reminiscences of a Busy Life, London I91 1, pp. 455-460.

2 Marginal notes by E. S. Beesly on his copy of Onslow Yorke's Secret History of the I.W.M.A., in the possession of Mr. Alfred Beesly. 
federalist and Republican sentiments and opinions which prompted the revolutionaries, but having pointed to these vague and sometimes conflicting ambitions of the insurgents, they returned to the class struggle as the essential relationship in terms of which all this diversity could be understood. "This struggle of the capital against the provinces, of the great cities against country, of the Republic against Monarchy, of Communal against Parliamentary government - what does it mean? There is one thing which inspires and causes these. That one thing is the struggle of the workman against the capitalist." 1 Beesly and his friends believed that the Socialists were in a small minority in Paris: a minority which was distinguished by its courage, energy and fanaticism. The Communards as a whole were not socialists, but workmen who were groping their way towards the political and social destination which Comte had long ago recognised as historically inevitable. If this half-formed, inarticulate positivism permeated the mass, there were a few others who were consciously participating in the revolution as disciples of Comte, and Beesly thought that the aims of the Revolution might owe something to their activities. ${ }^{2}$

The small group of Parisian Positivists, with whom Beesly and his friends tried to keep in touch, numbered among its members workers who were active in the Communal Government. Thus, Stupuy was secretary to the Arms Commission of the gth. Arrondissement, and another Positivist, the gifted but wayward Eugène Sémerie, was a member of the same Commission. ${ }^{3}$ Long before March I $87 \mathrm{I}$, these Parisian Positivists had placarded Paris to announce that "the legitimacy of a government derives neither from divine right nor from universal suffrage, but from its full harmony with the necessities of a given situation." 4 They called upon Parisians to testify to their consciousness of being citizens of the "Metropolis of the West" by returning Garibaldi, Jacoby, Pi y Margall and Richard Congreve as members of the Assembly. ${ }^{5}$

Indeed the attitude of the English Positivists to the Commune cannot be fully understood unless account is taken of a remarkable episode which their French co-religionists now recalled.

In August I 848 Littré, Magnin and Laffitte presented to Auguste Comte and the Positivist Society a project for revolutionary govern-

1 Harrison, F., The Revolution of the Commune, in: The Fortnightly Review, May 1871 .

2 Beesly, E. S., Professor Becsly on the Paris Commune, in: The Bee-Hive, I Apr. I87r.

3 "Jugement," Parisian Positivist placard, 3 Oct. 1870. (Le Chevallier, Murailles Politiques.)

4 Parisian Positivist placard, 18 Nov. 1870 . (Ibid.)

5 Placard by E. Sémerie, 6 Feb. 1871 . 
ment. According to this project, Paris was to be responsible for appointing the central government for the whole of France. In the recurrent revolutionary crises that marked the course of French politics, Paris did effectively determine the character of the French government. The scientific policy of Positivism therefore started from an acknowledgement of this real prerogative which belonged to Paris and, instead of setting itself against a relationship which was inherent in the relations between Capital and Country, sought to regulate it. The rule of Paris was calculated to place power in the hands of the workers, who were the people best qualified to direct affairs during the close of the revolutionary period. The workmen "not having received a metaphysical education, have fewest prejudices; belonging to the most numerous class, their views have the greatest generality; having the interests which are least implicated in local affairs, they display the greatest disinterestedness; finally, being the hardest pressed by the need for social reconstruction, they are the most energetically revolutionary section. On all these counts, it is just that political power in France should belong to Paris; and on all these counts also, power comes to the proletariat." 1

Beesly's articles in the Bee-Hive provided a most vivid (and on the whole an accurate and balanced) account of the Revolution in Paris. They brilliantly conveyed the spirit of the French proletarian and republican Left; for what Frederic Harrison's literary style owed to Carlyle, Beesly's owed to Rochefort, of whom he was a lifelong reader. ${ }^{2}$ Indeed it is as useful and necessary to consider Beesly in relation to the tradition to which Raspail and Rochefort contributed, as it is to see his place in that line of English philosophic radicals which stretches from Bentham to Webb. It was this which uniquely qualified him for the lonely task of upholding the Communards. His aim in these articles was to arouse the class feelings of his readers; to expose the distortions of the middle-class press; to state accurately the motives and purposes of the Communards, and to show their rising as "the first act of the most momentous historical drama of modern times."3

It does not seem likely that Beesly made much impression upon working-class opinion in England. A few responded to his impassioned arguments: a Republican leader in Hull, a tailor in South Wales, a shoemaker or two in London, and a young man named Belfort Bax

1 Sémerie, E., La République et le Peupele Souverain: Mémoire lu au Club Positiviste de Paris, 3 Apr. 1871 .

2 Beesly, E. S., Rochefort, in: The Birmingham Weckly Post, 22 Jan. 1870, and on Maxse in: The Positivist Review, Aug. I899.

${ }^{3}$ Beesly, E. S., Professor Beesly on the Fall of Paris, in: The Bee-Hive, 27 May 1871. 
who was to count for something in the subsequent development of organized socialism in England. ${ }^{1}$ The small pro-Communard section of the London working-class really owed nothing to Beesly or the Positivists, for they followed Engels in writing them off as "only going in for a compromise under middle-class leadership." 2

The most that can be said for Beesly's success is that he may have done something to prevent workmen from being infected with the hysteria which prevailed in other sections of society. Under the most favourable conditions, it would have been a hard task to persuade the workmen to keep pace with the French as they ran through the whole kaleidoscope of government.

It has to be appreciated that Beesly and the Positivists were in the position of men appealing from the inhabitants of one world to those of another. The chasm which separated working-class thinking in London and Paris can be demonstrated by means of one simple illustration. At the beginning of ${ }^{8} 871$ George Potter and other London workmen sat on a committee with Baron Rothschild. The object of this Committee was to raise a fund so that the Parisian workers might get their tools out of pawn. ${ }^{3}$ Meanwhile, across the Channel, this philanthropic gesture was being rendered superfluous by the Parisians themselves who were abolishing the pawn-shops!

If the majority of British workmen were not actively hostile to the Commune, then they were totally bewildered by it. The Left Wing in London had to acknowledge it. Engels could not find a good word to say for the English workers. ${ }^{4}$ Most of the trade union leaders seem to have supposed that the Commune could have been averted either by more philanthropy or by a timely translation of Cassell's Encyclopaedia of Useful Knowledge. The Bookbinders' secretary, T. J. Dunning, was speaking with the authoritative voice of the trade union oligarchy when he explained that economic categories were immutable, and that the Communards must therefore be mad, since they contemplated the abolition of rent. ${ }^{5}$

If the writings of Beesly, Bridges and Harrison got little response from workmen, matters stood very differently with the middle class. Lord Arthur Russell declared that "everybody" in the Reform Club

${ }^{1}$ Bax, E. B., Reminiscences and Reflections of a Mid and Late Victorian, London I918, pp. 30-3I.

2 Remarks by M. J. Boon, Minutes of General Council, 31 Jan. I87x. (I.I.S.H.)

3 The Mansion House Committee. The Bee-Hive, 8 Apr. I 87 I.

${ }^{4}$ Minutes of the General Council of the I.W.M.A., 8 Aug. 1871 , (I.I.S.H.)

${ }^{5}$ Dunning, T. J., The Commune in Paris, in: The Bee-Hive, 8 Apr. 187 I. 
thought Beesly to be a complete fool. "Everybody" knew that Frederic Harrison was even worse, since he flattered his ignorant clients in the interests of his political ambitions. "Everybody" knew that the Positivists were publishing calculated incitements to violence in the pages of the Bee-Hive. However, this last opinion was one which Lord Russell declined to test in a court of law. ${ }^{1}$

In a leading article entitled "Our Own Reds," the Pall Mall Gazette declared that the "Comtist agitators... make known to us a spirit as reckless, as cool-blooded, as well-leavened with political hate, as unscrupulous in the machinations of turbulence as ever possessed the revolutionaries of any age or nation - all of which we shall see fully displayed if malign chance gives them that ascendency over working men which they strive so hard for."2

Even their "own" organs, the Fortnightly Review and the Bee-Hive carried articles in which Beesly and his friends were savagely attacked. Colonel Chesney, in the Fortnightly, imagined that "malign chance" had given the Positivists ascendency, and drew a fearful picture of the fratricidal strife which ensued when a ruling triumvirate of Harrison, Beesly and Odger was obliged to defend its power and its life before a deadly new combination consisting of Congreve and Bridges. ${ }^{3}$ In the Bee-Hive, Potter allowed Beesly to be subjected to a series of violent personal attacks by a whole host of middle-class contributors. ${ }^{4}$ It was suggested that he wanted a revolution in England so that he could be made President of the Republic. His writings were described as "pestilential heresies," and after the fall of the Commune - for which the Positivists were alleged to be responsible - Beesly and his coreligionists were invited to try "forty days of humility and silence."

"Everybody" lumped the Positivists together with the Communists. Even Sir Thomas Larcom, member of the Privy Council in Ireland, kept a file of newspaper cuttings of Positivist activities along with those of the International, adding a note to the effect that Positivists were similar to Communists - irresponsible and seditious people. ${ }^{5}$ It was in vain that Beesly insisted that Positivism was distinct from Communism and ought not to be confounded with it. Mr. Punch was expressing the prevalent view when he observed, "Never-the-less,

\footnotetext{
1 Russell, B. \&. P., The Amberley Papers, I937, Vol. II, p. 462 et seq.

2 Our Own Reds, in: The Pall Mall Gazette, 19 Apr. 1871.

${ }^{3}$ Chesney, C. C., letter in The Fortnightly Review, Nov. 1871 .

4 Aytoun, J., Trade Unions versus Communism, in: The Bee-Hive, I July I871. Neville, C., The Commune, in: The Bee-Hive, 27 May I 87 I. Storr, J. S., The late Commune and the Comtists; Modern Revolutions; Infamous, in: The Bee-Hive, 3 ; 10; 17 June $187 x$.

${ }^{5}$ Sir Thomas Larcom Collection, Micro-film from National Library of Ireland, File headed "Mr. Harrison." (Kindly lent by Mr. C. Abramsky.)
} 
confound them both." Marx and Beesly were both pilloried mercilessly, and if an informed and respectable English gentleman had been asked which of them was the worse, he would have had to reply as Dr. Johnson did when it was enquired whether he thought Rousseau as bad a man as Voltaire, "Sir, 'tis a nice matter to proportion the degree of iniquity between 'em."

Indeed, the two men were both subject to one common calumniator in the Pall Mall Gazette, edited - at this time - by Frederick Greenwood, soon to become notorious himself, for his part in the Suez Canal shares deal. Marx went so far as to hint that he would have challenged Greenwood to a duel had they been living on the continent, ${ }^{2}$ while Beesly engaged him in a long and bitter correspondence which arose out of the charge that he (Beesly) had been uttering or echoing "wild screeches for blood and fire."3 Beesly wrote to Marx enquiring about Greenwood and received the following choice reply:

"My dear Sir, Enclosed the photograph for Mrs. Beesly. The Christian name of the illustrious Greenwood is Frederick. Ce n'est pas Frédéric le Grand. Vous savez que Voltaire, dans sa retraite suisse, avait auprès de lui un jésuite, nommé Adam, qu'il était accoutumé à representer à ses visiteurs en disant: ce n'est pas le premier des hommes! Jenny will give herself the pleasure to call on Mrs. Beesly on Wednesday next about I o'clock. Yours most sincerely, Karl Marx." 4

It would have been less than generous of Marx to have done anything but express his admiration for Beesly's articles in the Bee-Hive. He did so, but tempered praise with caution. He was "almost sorry" to see Beesly's name in that journal. He declared it was "the organ of the renegades, sold to Sam Morley and Co." The Eastern Post, he implied, was the only honest paper, which did something like justice to the pronouncements of the International, and in which Beesly could write without making a "sacrifice" to "the good cause."5

Beesly certainly had no love for Potter, Morley or the Bee-Hive from which he had dissociated himself completely on more than one occasion, but he was not prepared to deprive himself of a useful channel

1 The learned and logical Professor Beesly, in: Punch, 9 Dec. 1871.

2 Karl Marx to the editor of the Pall Mall Gazette, 30 June 1871 . Published in The Eastern Post, 8 July 1871 . (See Marx' explanation in his letter to Kugelmann, 27 July 1871 .) ${ }^{3}$ Beesly-Greenwood correspondence: The Bee-Hive, 28 Oct. 1871 and The Eastern Post, 4 Nov. 187 I.

${ }^{4}$ Marx to Beesly, 19 Oct. 187 I. (Photostatic copy of letter in possession of Mr. Alfred Beesly.)

${ }^{5}$ Marx to Beesly, I 2 June 1871 . (Sel.Corr. Torr.) 
of communication, and in $187 \mathrm{I}$ he continued to write for it. However Marx' reference to the Eastern Post had its effect. "If it has a good circulation among East End workman," he wrote, "I would rather write in it than in the Bee-Hive." 1 He told Potter this and duly wrote a series of articles for the Eastern Post. ${ }^{2}$

Marx went on to make a further point quite clear: he might respect Beesly's intelligence and entertain fraternal feelings towards him, but he had no time at all for Comte. Marx observed, "as a Party man I have a thoroughly hostile attitude towards Comte's philosophy, while as a scientific man I have a very poor opinion of it." In short, he gave Beesly to understand that he was " a good man fallen among Positivists". As if to prove the sincerity of his personal respect, he went on to give a lot of detailed confidential information about his communications with Paris, and how he had secured, ${ }^{3}$ - by what amounted to fear of blackmail - "all the details of the secret agreement come to between Bismarck and Favre in Frankfort." Beesly feared for the safety of his co-religionists in Paris. Apart from a report that Sémerie was arrested, he had heard nothing and could only hope that "possibly those who escaped the first fury may not now be executed."4 So Marx in this letter, which was a reply to Beesly's one of the same date, went on to state that he was prepared to consider any commissions which Beesly or his friends might have in Paris, and which he could handle for them through one of his agents.

Beesly lost no time in replying to this letter. "I know very well that you are radically opposed to us Positivists," he wrote, "nor do I suppose it at all likely that you will ever alter your views. The one point we and you have in common is our indignation against the individualist theories of the propertied classes and their anti-social conduct. We both believe that the working class suffer terrible wrongs at the hands of the middle class, and that the social question is more important than the political. You are quite wrong in supposing that my attitude differs in any respect from that of my co-religionists. Harrison at bottom agrees with me, though in writing he is inclined to be too diplomatic, in my opinion, and to spare the susceptibilities of the middle class. But Congreve (our director) and Bridges have warmly approved all that I have written. Congreve though suffering

1 Beesly to Marx, I 7 June 187 i. (M.E.L.I.)

2 See eight articles by Beesly in The Eastern Post between 8 July 1871 and 26 Aug. 1871 .

${ }^{3}$ From Johannes Miquel, not Lothar Bücher [sic] as asserted by D. Torr (Sel. Corr. Torr, p. 3 ${ }^{14}$ ). The impression created by Marx was that fear of blackmail and not personal friendship explained how he got information from Bismarck's "right-hand" man.

4 Beesly to Marx, I 2 June I 87 I. (M.E.L.I.) 
from great... [word illegible] stood up at our weekly meeting before many strangers and declared that history would look back on the burning of the public buildings in Paris as a solemn symbolical protest against material magnificence and the worship of wealth. Our members in Paris, though hostile to Communism, have not intrigued against or opposed the Commune, but have frankly served it and risked their lives for it. All the English Positivists have been ardent supporters of it from $x 8$ th. March. No doubt whenever it becomes a practical question whether private property is to be abolished, you will find us opposed to you firmly. But it is likely that long before then we and you shall have been crushed side by side by our common foe." 1

This was an advance on Marx' letter in so far as formulating the common ground was concerned, although it fell far short of a full or adequate statement of the affinities that existed. As for Beesly's insistence on the identity of view between himself and his co-religionists, here an extravagant over-emphasis on differences is met by an over-simplifying denial. For the rest, Marx could not fail to be aware from the Press of the Positivist position. They had publicly made it clear that they thought Communism was a one-sided and unworkable system and that private property was a source of "infinite holiness." They repeatedly asserted that Positivism was the only alternative to Communism. ${ }^{2}$ Far from distressing Marx this insistence on the differences between Positivism and Communism probably pleased him, and his letter to Beesly suggests that he may have been anxious for further reiteration. It has just been shown that the two systems and their advocates were being confounded by important sections of public opinion. It was surely a matter of the highest importance to Marx that his reputation as leader of the International and defender of the Commune should not be shared - and by being shared, confused and reduced - with anyone; whether it was Bakunin, Professor Beesly, or J. Johnson, "the Marat of Walworth Common".

Marx could only have thought it all too good that Beesly and his friends insisted on presenting themselves as a completely independent group. He did not want their far-fetched nostrum fathered upon him, and it was a decided advantage that a non-socialist group could be found ready, in public and in private, to affirm that the Communists were the real leaders of the insurrection, and entitled to be by virtue of their superior resolution, courage and clear-headedness. It was worth any amount of Positivist crotchet-mongering and innocent misrepresentation of theoretical questions, to have Beesly or Bridges

1 Beesly to Marx, 13 June 187 I. (M.E.L.I.)

2 Beesly, E.S., The Communists, in: The Bee-Hive, 29 Apr. I87r. 
publicly and explicitly referring to the correctness of Dr. Marx' views on the error of the Communards in not taking the offensive, and the primary responsibility of Thiers for the death of the Archbishop of Paris. ${ }^{1}$

This key point is interestingly illustrated by a passage in the Civil War in France. Towards the end of that famous address Marx refers to an "honourable French writer, completely foreign to our Association" who had spoken as follows:

"The members of the Central Committee of the National Guard, as well as the greater part of the members of the Commune, are the most active, intelligent and energetic minds of the International Working Men's Association.... men who are thoroughly honest, sincere, intelligent, devoted, pure and fanatical in the good sense of the word!"

Marx did not state the name of this "honourable French writer" whose glowing opinions could be so usefully set against those of the "policetinged bourgeois mind," but in fact it was Auguste Comte's physician, Dr. Robinet, a leading Parisian Positivist and for some time deputy mayor of the 6th. arrondissement. Beesly had thought it worth while to get extracts from Robinet's letters to English Positivists translated, and he himself wrote a brief introductory note to the pamphlet. Because it might have imperilled their co-religionists' safety for the author to have been identified, the Positivists for once relaxed their scruples against anonymity. ${ }^{2}$ Robinet was not a member of the International, but he was closely enough identified with the Commune to make him extremely gloomy about his prospects in the event of a bourgeois victory. He told Congreve that if he must die, then he would die fighting. He would fight as the best of the Communards fought - for the Republic and for Humanity. He committed his wife and children to the care of his British and American co-religionists. ${ }^{3}$

It was this pamphlet from which Marx quoted, and it was these circumstances which explained - at least in part - why the name of the author was not given. However, Marx actually ran together different passages from the pamphlet and did not indicate that Robinet meant his favourable judgement to relate only to the proletarians and small

${ }^{1}$ See particularly, Bridges, J. H., The Late Commune of Paris; and Dr. Bridges on the Commune of Paris, 22 and 8 July 1871.

2 "A French Positivist": Political Notes on the present Situation of France and Paris, with an introductory note by E. S. Beesly. - The identity of the author is established by comparing the letters in the pamphlet with the obituary note on Robinet by J. H. Bridges in The Positivist Review, Dec. I899.

${ }^{3}$ Congreve to Henry Edger, 22 June 1871. (MA.C.) 
engineers in the I.W.M.A., and not to the literary men and journalists who joined them later. ${ }^{1}$

Beesly apparently did not think it worth while to quibble about this point. He was immensely impressed by Marx' work, and told him that he looked on it "as a most valuable history of the last twelve months. The facts are admirably grouped, and stated in forcible and elegant language." He allowed himself only two criticisms, both of which have since become very familiar.

The first was that "as far as English workmen are concerned, it would have been an advantage if some expressions and allusions had been somewhat less foreign in style. But on the other hand, it is undoubtedly much to be desired that our workmen should be familiarised with continental terminology and ideas."

The second was that it was "indistinct and unsatisfactory" for Marx to state that "the workmen have no ideals to realise, but to set free the elements of the new society with which old collapsing bourgeois society itself is pregnant." "I think," said Beesly,

"it is not superfluous, but on the contrary, imperative upon you to state clearly not only what immediate economic measures you proposed to take, but also what ulterior course you wish to follow. As a matter of policy you can lose nothing by it with public opinion, since you are already credited with the most extreme revolutionary designs with respect to property. Your projects, even the mildest of them, are, of course, certain to be criticised by the middle class from the point of view of absolute rights and justice to individuals. I suppose you know enough of Positivism to be aware that no such metaphysical objections will come from us. Let it once be shown that any measure is for the good of society as a whole, and we call upon individuals to be silent. We are also quite ready to distinguish between the normal condition which concerns the thinker, and the temporary or revolutionary expedients which must be left to the judgment of the practical leaders." 2

Plainly Beesly did not recognise that part of the secret of Marx' greatness as a philosopher of history and prophet was that he knew when to hold his tongue, whereas Comte was not only unsatisfactorily vague, but also incautiously precise. The French philosopher may have founded his philosophy upon experience, but within his system

${ }^{1}$ Compare Marx, The Civil War in France, penultimate paragraph, with "Political Notes...," Letters $I$ and 3 .

2 Beesly to Marx, 17 June 187 I. (M.E.L.I.) 
future experience is rigorously circumscribed by the pedantic detail with which the new society and religion are described. He thus laid himself open to the mockery of one of Marx' wittier later-day disciples who remarked that Comte seems to "composer le plan de la science future comme le programme annuel des cours pour une promotion de l'X."' Still, despite these criticisms, Beesly was anxious that the "Civil War in France" should have a large circulation among English workmen, and he discussed in some detail how this result might best be secured.

A letter which Beesly addressed to Marx a few days later throws an interesting sidelight on another aspect of their relationship. It suggested that the strengthening of the parliamentary position of Thiers was to be welcomed, since the bourgeois Republic would permit something like freedom of the press and meeting, and because "Parliamentary Government in France inevitably leads to revolution sooner or later." Beesly attached to this letter a note sent to him by the Private Secretary to Mr. Bruce, the Home Secretary in the Gladstone Government. This note enquired if it would be possible to obtain "from public sources" any information about the International and a list of the documents it had published. ${ }^{2}$ Presumably it should be interpreted in the context of Jules Favre's circular to the Great Powers calling for action against the International.

The fact was that Beesly had a number of channels of communication not only with the "Left-Wing" of the Liberal party (Mundella, Hughes, Joseph Cowen, Stansfeld, John Morley and others) but with people in the higher branches of the Civil Service, particularly the Home Office: a fact which, as has been shown, did not prevent him from being "booked" in the files along with other "subversive" persons. Probably most of his "inside" information came through Godfrey (subsequently Sir Godfrey) Lushington, son of a distinguished Admiralty Court judge and first legal adviser to the Home Office. Lushington and his twin brother Vernon were both foundation members of the London Positivist Society. There is evidence that Lushington passed semi-confidential information to Beesly, ${ }^{3}$ and he

\footnotetext{
1 Prenant, Lucy, Karl Marx et Auguste Comte, in: A la Lumière du Marxisme, Tome II (Paris 1957), p. 73.

${ }^{2}$ Rutson, A., to Beesly, and Beesly to Marx, 5 July 187 r. (M.E.L.I.)

${ }^{3}$ Beesly confronted Alexander Macdonald with information relating to negotiations in the Home Office concerning the Mines Regulation Bill of 1872 . See his charges in The Bee-Hive, 24 Aug. 1872. The Home Secretary was disgusted with Macdonald and probably welcomed these disclosures. Bruce, H. A., Letters of Lord Aberdare, Vol. I (printed for private circulation).
} 
certainly played a large, if somewhat imponderable part in the final triumph of the trade unionists' labour laws agitation.

Another letter of Beesly to Marx written about the same time illustrates the range of the Professor's acquaintance with the political opinion of the time.

"I return your Shilth's [?Smith's?] letter. He is evidently a highly intelligent and well-informed man. I wish I could think that there were many such in his class. Until there are, I am afraid we shall move very slowly towards a better social state. ${ }^{1}$ I think a political revolution may happen at any moment. Lord Salisbury ${ }^{2}$ who is a very able man, very clearsighted and with a determination not to delude himself but to see things as they really are, told a friend of mine that he did not expect the House of Lords to last ten years and therefore it was not worth while to make any attempt to strengthen and reform it, as for instance by life peerages. He is something like Bismarck. He loathes the idea of democratic and social change. He thinks England will not be worth living in when that comes. But he is fully convinced that it must come. Only he thinks it may be postponed, and he is determined to fight tooth and nail for every inch of the ground. $\mathrm{He}$ labours to reconcile and bind together all the propertied classes, mercantile as well as territorial, in resistance to the needy."

Beesly then went on to draw Marx' attention to the evidence given by James Geddes before the Indian Finance Commission. Geddes was one of a number of highly distinguished young Positivists who were in the Indian service, and it is worth noting that it was none other than James Geddes who first shook H. M. Hyndman's faith in the beneficent consequences of British rule in India and set him off on the track that led to socialism and meetings with Marx. ${ }^{3}$

Beesly told Marx that he would find Geddes' evidence "very remarkable. The signal for the grand crash will come from India. We

1 One conjectures that the letter referred to was by Tom Smith, a Nottingham workman and member of the International. He wrote a series of letters on the Commune in the Nottingham Daily Express which were subsequently published in a widely discussed pamphlet entitled "The Law of the Revolution" upon which J. S. Mill and others passed judgment. This is probably the only work by an Englishman which will stand comparison as a defence of the Commune with the articles by the Positivists.

${ }^{2}$ Robert, third Marquis of Salisbury, I830-1903, four times Prime Minister of Conservative Governments. The opinions attributed to him by Beesly are in character. (Life: by his daughter, Lady Cecil).

3 Gould, F. J., H. M. Hyndman: Prophet of Socialism, London 1928, p. 51. (Gould was both a Positivist and a Socialist.) 
are slumbering upon a volcano there. If we do not hasten to withdraw while we can, we shall soon be overtaken by appalling disasters, and it is very certain that our constitution will not stand any extra strain. The first great war in Europe or Asia will bring on revolution.... We shall be staying here (Lady Crompton's house at Chorley) some three weeks longer. The country is very delicious now. I expect to be in town the last week in August and then go to the seaside for September. I shall try to see you if possible when I am in town." 1

It was indeed one of the curiosities of the Positivists' position that, like their illustrious predecessors, the Utilitarians and their equally illustrious successors, the Fabians, they managed to preserve contact with both the "Establishment" and those in conflict with it. Thus, Henry Crompton explained that his action in the labour laws agitation was not too dangerous to him personally because he held a judicial appointment and because of what he termed "the fact of my strong position with the trades unionists and the important fact of my being permanently [sic] known to so many members of the House of Commons on both sides." He explained that a man "who is permanently known to the House, or to a large number of members may go a long way - and do things with impunity for which another unknown man would be sacrificed". For the sake of completeness it should be explained that Crompton, writing in 1878 , added this rider: "But the truth is that I have been very useful to the Conservative Government both in the Labour Law question, and the magistracy reform, and the codification question, - the latter two of which are pending Government measures - in which the support and assent of the Trades Unionists is wanted and which they are not likely to get except through influence like mine." 2 Beesly, however, could hardly have been said to have been "very useful" to the Liberal government of I 868-1 874 .

When the Communard refugees began to arrive in England, both Marx and Beesly did what they could to promote their security and reduce their sufferings. As early as Ioth. June Beesly was pointing out to Marx that "the Times, Pall Mall and Saturday Review are evidently of opinion that our law courts will decide that no Communist refugees can be surrendered for any acts whatever done during the Civil War. I hear some of them have arrived." 3

If this was the construction originally put upon the law relating to

\footnotetext{
${ }^{1}$ Beesly to Marx, 27 July I 871 . (M.E.L.I.)

${ }^{2}$ Crompton, H., to J. Geddes, 14 May 1878 . (P.A.B.M.)

3 Beesly to Marx, io June 187 I. (M.E.L.I.)
} 
extradition by the middle-class press, it ought not to be taken to mean that they were not ready - some sections of them - to hurry the Communards back to the "shambles of Thiers."1 Particularly, after the execution of the Archbishop, a section of the press became ghoulish, and recommended the use of defeated Communards as subjects for vivisection, carefully stipulating that no anaesthetics should be used. Manning, who subsequently earned renown as a friend of the dockers, wanted them treated "like pirates."2

Marx, Beesly, and their friends did what they could to arouse opinion against any and every proposal for the extradition of Communards. The danger was real. At one point Lord Granville, the British Foreign Minister, was ready to announce to the world that Britain would pass new laws which would prevent the right of asylum being "abused." He was restrained, not by Beesly or Marx, but by the wisdom of the British Ambassador to Paris who reminded him that "the existence, in the hands of the Government of a power to expel foreigners might expose us to frequent and very inconvenient demands from neighbouring countries for the exercise of that power."3 In the end Lord Lyons' counsel prevailed over that of other powerful voices, such as those of the law Officers of the Crown, who did not conceal their alarm at what they termed the influx of "dangerous, pauper Frenchmen."4

Neither Beesly nor Marx appear to have discovered the real object of the policy which came to be evolved conjointly in the Home and Foreign Offices. The object of this policy was not to extradite refugees who had reached Britain, but to prevent any more from arriving, and to do this without formally denying traditional rights of asylum. The number of Communards who reached Britain was likely to be limited by the difficulty most of them would experience in raising the money for the journey. But the French authorities, wishing to force Britain to adopt policies more in line with France's continental neighbours - subsidised those who were sentenced to excile and expressed a wish to go to Britain. The British Ambassador repeatedly protested against this action of the French Government. ${ }^{5}$ But M. de Rémusat cleverly countered these protests by enquiring as to the grounds of Britain's

1 Beesly, E. S., Professor Beesly on the Paris Massacres, in: The Bee-Hive, 3 June 187 I.

${ }^{2}$ Congreve to Lobb (undated). (Congreve Colleetion, Wadham.)

${ }^{3}$ Lord Lyons to the Earl Granville, I7 May 1872 . (Home Office Papers. Public Records Office. (H.O. 45. II $335 / 14$ \& I5.)

4 The Law Officers of the Crown to the Home Secretary, 31 May 1872 (Home Office Papers. H.O. 45. I1335/22.)

5 Lord Lyons Despatch (No 653) to Earl Granville, 24 May 1872. (Home Office Papers. H.O. 45. $11335 / 19$.) - Records protests. 
complaint against France. Surely the British Government would not have the temerity to question how France chose to deal with prisoners held within her own territories? Since His Excellency, the British Ambassador, could not have intended to interfere in France's internal affairs, what precisely was it that he required of the French Government? Should communard exiles be "previously informed of the opposition made to their choice of Great Britain as their place of residence. We could not certainly cavil at the Queen's Government if, in future, they wish to exclude from British territory foreigners whose presence in England might appear injurious; but if such is really the rule which the Cabinet of London means to apply to individuals expelled from France for having taken part in the last insurrection at Paris, I should be glad to receive from your Excellency a positive announcement to that effect." 1

The British Government had to take great care in dealing with this cunning manouvre. If it publically protested, it might be reminded that Britain had herself paid the expenses of Fenians to the United States. ${ }^{2}$ It therefore confined itself to studiously vague objections to the French Government's actions which it described as "a serious breach of international commity." 3 The French replied that they had decided to keep the exiles in prison until such time as the British Government chose to clarify its position. ${ }^{4}$ This, the British Government could not or would not do. The whole tragicomic episode ended on a bizarre note; a memorandum was despatched to Versailles on British experience of the expense and dangers of transportation as a method of dealing with criminals and undesirables $!^{5}$ One can only conjecture as to how Marx and Beesly would have lashed the "infamous, hypocritical Whigs" had they learnt of this.

In addition to staging a vigorous defence of the right of asylum Marx and Beesly tried to find work for the refugees. So did Frederic 1 Official translation of letter by the French Foreign Minister to the English Ambassador, 18 March 1872. (Home Office Papers. H.O. 45. 11335/4.)

${ }^{2}$ Memo of 24 Apr. 1872 by the Home Secretary to the Solicitor of the Treasury asking him to obtain an opinion from the Law Officers of the Crown as to whether the banishment of Fenian Prisoners "and the payment of their passage to the several places to which they elected to go, could be used by the French Government as a justification of their proceedings..." (Home Office Papers. H.O. 45. Ir335/10.)

${ }^{3}$ Lord Lyons to the French Foreign Minister, I2 Apr. 1872. (Home Office Papers. H.O. 45 . I1 $1335 / 17$.)

4 Lord Lyons reports to Earl Granville, 27 May 1872. (Home Office Papers. H.O. 45. II $335 / 20$.)

${ }^{5}$ Memorandum for the French Government on British experience of Transportation drawn up by Major Du Cane, Surveyor General of Prisons. (Home Office Papers. H.O. 45. $11335 / 3 \mathrm{I}$.) This was acknowledged with thanks by Rémusat in a letter to Lyons. (Home Office Papers. H.O. 45. Ir 335/31 \& 32.) 
Harrison, who wrote long letters to Mundella and Cowen, imploring them to find some livelihood for the penniless Frenchmen. ${ }^{1}$ He told Mundella that:

"The refugees are dying here. There are about 100 of them that I know of simply starving - without clothes or shoes - ...the various charitable societies will have none of them.... One of them can speak eight European languages, knows Sanscrit and can teach mathematics and engineering, and he is literally starving! He has twice refused money. Another to whom I sent a cheque has not cashed it.... Their own compatriots here are as savage as those from whom they escaped."

Almost every letter by Beesly to Marx at the end of 1871 and the beginning of 1872 dealt with this problem:

"My dear Sir, I hear General La Cecilia is in great distress. Can you give me his address? I might perhaps get him some work. If he calls here on Friday at $\mathrm{I} \frac{1}{2}$ I shall be glad to see him." 2

"My dear Sir, I am sorry to hear that General Wroblewski ${ }^{3}$ is ill. I am a subscriber to University College Hospital and I will give a ticket of recommendation...." 4

"I will enquire whether any extra diet or stimulants are needed for the General and will take care that he has them as soon as I return to town. In the meantime may I ask you to pay for him any expenses immediately necessary (such as arrear of rent, taking things out of pawn, conveyance to Hospital) within the limit of $£ \xi$ and I will reimburse you...." 5

"My dear Sir, I received this morning a letter from an eminent Professor at University College Hospital whose kind attention to General Wroblewski I had bespoken in which he informs me that he has seen nothing of him.

I cannot suggest to myself any explanation of your silence of more than a fortnight with respect to the General. I counted confidently on a reply to my last note." 6

${ }^{1}$ Harrison, F., to Mundella, 29 Dec. 187 r. (Mundella Collection, Sheffield University Library.)

2 Beesly to Marx, I 2 Dec. 1871. (M.E.L.I.) - La Cecilia shared military command with Dombrowski and Wroblewski.

3 Wroblewski W.: r 836-r908. Talented strategist and Communard Commander in Chief.

4 Beesly to Marx, 22 Dec. 1871 . (Ibid.)

${ }^{5}$ Beesly to Marx, 22 Dec. 187 I (a further letter). (M.E.L.I.)

${ }^{6}$ Beesly to Marx, 6 Jan. I 872 . (Ibid.) 
"My dear Sir, If M. Durand [? - name not fully legible] could scrape together the rest of the fund necessary to take him to Switzerland, I would subsribe $£ 2$ towards it. I can do no more. Nor can I donate as much as that to the case of one individual except for the well-assured purpose of sending him away and lessening pro tem[?] the mass of [... ?] poverty here.

I have found 54 pupils for French exiles. But I have no more openings left.... Did you see the attack on Harrison and me for what we have done to save these poor fellows from starving in the Observer yesterday? It is no doubt from the pen of the editor, Edward Dicey." 1

It was with these melancholy matters that the period of close collaboration between Beesly and Marx came to an end. Both men had made themselves thoroughly unpopular with the ruling oligarchy in the British labour movement. Just as Marx had thrown all discretion to the wind and publicly declared that it was an honour not to be a recognised English Labour leader, so Beesly had gone a long way towards making himself persona non grata with the top people in the Trade Union movement. While the Civil War had been raging in France, the Liberal Government's long-awaited Trade Union Bill had come before Parliament. Beesly had not hesitated to relate the two events in a manner which the new Parliamentary Committee of the T.U.C. found highly embarrassing. While they were supplicating before a middle-class Parliament, their acknowledged counsellors were applauding the Communards for finishing with Parliaments which were nothing but the chosen instruments of bourgeois rule. When the Lords' amendments to the Trade Union Bill became law - thus necessitating a further four years of agitation - Beesly told the unionists that this was what became of their narrow, petty preoccupations, of their profane indifference to the fate of the Paris Commune. The defeat of the Communards had, he alleged, convinced the middle and upper classes that, whether tested at the barricades or the polling booths, the power of the workers was a delusion. ${ }^{2}$

If this explanation of the unionists' defeat seemed inadequate Beesly was at hand to supplement it with another one which was even more unwelcome to union leaders. Workmen, he stated bluntly, had been sold at the election of I 868. Certain secretaries and officials of the Unions had got money or "money's worth" by serving wealthy

\footnotetext{
1 Beesly to Marx, 5 Febr. I872. (Ibid.) - Edward Dicey had been a contributor to the Fortnightly Review, foreign correspondent for the Telegraph and, for three months editor of the Daily News before moving to the Observer.

2 Beesly, E. S., The Division on the Trades Union Bill, in: The Bee-Hive, 29 July 1871.
} 
politicians instead of looking after the interests of their members. ${ }^{1}$ It seemed to Beesly at this time that the whole "labour aristocracy" was subject to a growing degeneracy. "Many intelligent workmen", he observed,

"fall away, regretting the selfish paths they might have followed; others convert politics into a trade and pursue with mean calculation the course they originally entered on with high purpose. Others mistake their own ambition for public spirit, and persuade themselves that they are jealous for a good cause, when they are feeding some grudge or scheming against some personal rival. A few only remain pure, earnest and simple-minded: and even of them too many become crotchety and fanatical, animated not by the large and beautiful enthusiasm of their youth, but by a gloomy pride in the solitary possession of some fragment of truth unappreciated by the rest of men." 2

Beesly's charge of corruption aroused the indignation of honest men, such as Daniel Guile, ${ }^{3}$ as well as that of the culprit at whom it was aimed. George Howell, now secretary of the Parliamentary Committee of the T.U.C., was foolish enough to take the bait and publicly denounce the Professor for his "dastardly" and "unmanly" attack."

From this point forward it was Henry Crompton who became the principal Positivist adviser to the Trade Unions. He had a gentler nature than Beesly, he did not go round like Harrison and Beesly telling Howell and his compatriots that they were bought men; ${ }^{5}$ he did not talk about the "Party of Blood" existing in England in great force. 6 and - above all - he did not publicly raise his voice in defence of the Parisian "roughs," the "poltroons of Belleville."

\section{$\mathrm{V}$}

During the last ten or twelve years of Marx' life Beesly and he continued to be on friendly terms, but they ceased to work closely together. There were occasional supper-parties at which Marx sometimes accompanied by his wife, by Engels or by a friend from the continent - dined with the Beesly's at University College Hall in

1 Ibid.

${ }^{2}$ Beesly, E. S., A Rallying Point, in: The Eastern Post, 29 July I 871.

${ }^{3}$ Guile, D., Professor Beesly and Trade Society Secretaries, in: The Bee-Hive, s Aug. I871.

4 Howell, G., Professor Beesly and the Pall Mall Gazette, in: The Bee-Hive, 4 Nov. 1871.

5 Matx to Engels, II Dec. I876. (Marx/Engels Gesamtausgabe.)

- Beesly, E. S., Comparative Atrocity, in: The Bee-Hive, 1o June 1871 . 
Gordon Square. Sometimes John Morley, Captain Maxse or some other lion of English Radicalism would be present. ${ }^{1}$

Marx sent the Professor the livraisons of the French translation of Capital. These came in parts and, as they arrived, Beesly acknowledged them with warm thanks, explaining that: "I shall take the earliest opportunity of studying it with all the attention it deserves,"2 or, "I promise myself great interest and pleasure in reading your work as soon as I have finished what I am now busy about - the translation of Vol. III of Comte's Pol. Positive."3 One conjectures that these delays and interruptions proved interminable, for, while Beesly would have enjoyed such chapters as the one on "The Working Day," he would have found the Theory of Value a fatiguing subject, that recalled Comte's peremptory dismissal of all "tedious" discussions of the origin of wealth. When she was a young girl Beatrice Webb wrote a critique of Capital, which was sent to Beesly. When he failed to see the point she was trying to make she concluded that he did not think much of it or rather, like it. ${ }^{4}$ It seems more probable that with Beesly, as with others, an acquaintance with Marx did not extend as far as Capital. Not that the Positivists did not number some quite formidable economists among them. The Irish Positivist, J. K. Ingram, was an important figure in the history of economic thought, while Frederic Harrison's attacks on the "plutonomists" are not to be despised. They contain many anticipations of Thornton and Cliffe Leslie.

There were at least two matters of some small importance upon which Marx, in the last years of his life, sought Beesly's help. In 1878 Marx once again consulted the Professor about placing an article in an English periodical. George Howell had just written an account of the International in the Nineteenth Century which contained, amongst other things, the strange assertion that Marx wanted to raise the "Religious Question" at the Geneva Conference. Marx prepared a reply, which Beesly imagined "Mr. Knowles will be very glad to have." (Knowles was the editor of the Nineteenth Century.) "If he refuses it, I think Morley would probably receive it. I don't think either one or the other would make any difficulty, only you have laid on the lack a little more fiercely than is usual in our periodicals. I will write today to Morley." 5

1 Beesly to Marx, 17 July I871, 5 Nov. 1873, 10 Apr. 1874 . (M.E.L.I.) See also two notes by Beesly to Marx in the I.I.S.H.

2 Beesly to Marx, 7 Oct. I872. (M.E.L.I.)

3 Beesly to Marx, 18 Dec. 1875 . (Ibid.)

4 Webb, B., My Apprenticeship (Re-Issue), London I929, p. 294.

${ }^{5}$ Beesly to Marx, 8 July 1878. (M.E.L.I.) 
Neither Knowles nor Morley would touch Marx' article, which he was obliged to publish in a relatively obscure journal, the Secular Chronicle. It is interesting to note that Howell, whom Marx characterised as a "pseudomorph," wrote in his draft autobiography that he never thought of the I.W.M.A. as a revolutionary body, but considered that its aims could best be expressed in the Positivist maxim, "Order and Progress." Shortly after he wrote his article on the International, Howell was discussing with Henry Crompton the question of his becoming a formal adherent of the "Congrevian" (non-Beesly) group of Positivists. ${ }^{1}$ There had been a split in $1877^{-8 .}{ }^{2}$

The second matter upon which Marx consulted Beesly was the trial of Johann Most, who had fled to England after the passage of the antisocialist laws, and who was in $188 \mathrm{I}$ charged with incitement to murder, as a result of words written by him in Freiheit acclaiming the assassination of Alexander II of Russia. (Freiheit was published in London.) According to Engels, anyone who asserted that Marx gave any sort of assistance to Most, or had anything to do with him after he became an anarchist, had either been deceived or was a deliberate liar. ${ }^{3}$ However, a letter by Beesly to Marx written in April 1881 makes it clear that this requires some qualification, since Marx was interesting himself in Most's defence:

"It has been suggested to me that Mr. John Macdonell of 4 Pump Court, Temple, is a barrister well qualified to be retained for the defence of Herr Most, on the ground that he has a thorough acquaintance with the German socialist movement. Whether that constitutes a qualification I do not know. I know him slightly. $\mathrm{He}$ is an able man, a good writer, and expresses himself clearly in conversation. Whether he has the requisite qualifications for influencing an Old Bailey jury $I$ have not the least idea. But as the suggestion has been made to me, I pass it on to you, in order that you may make enquiries about Mr. Macdonell if you think it worth while. Of course the case will depend largely on skilled advocacy. Yours sincerely, E. S. Beesly."4

This letter has been given in full so that the reader may judge for himself whether it was unsolicited.

On Ireland, and on questions of foreign policy, there was the same

1 H. Crompton to G. Howell, 2 and 30 Dec. 1879 . (B.I.)

2 This split was a most interesting and extraordinary affair which throws a great deal of light on the character of the English Positivists. There is no adequate public account of it, nor room to give one here.

${ }^{8}$ Engels to Van Patten, I 8 Apr. 1883 . (Sel. Corr. Torr.)

4 Beesly to Marx, 14 Apr. 188 I. (M.E.L.I.) 
general accord between Marx and Beesly as there had been in the earlier period, but the considerations which took them to the same or to similar conclusions were often very different. Thus, they were at one in opposing the Gladstonian peace policy in the Balkans in $1877^{-} 78$, and Marx and his friends spoke in much the same way about the labour leaders turning themselves into a tail of the Liberal party on this and others matters, as did Beesly and his friends. But if Marx' policy proceeded from his obsession with the reactionary role of Russia, the governing idea with Beesly was the restoration of French security and influence in Europe. Like Marx, Beesly regarded Gladstone's pacifism, his denunciation of the Bulgarian horrors, as a mixture of theological prejudice and party calculation. In Positivist eyes Gladstone was likely to encourage the Russians to embroil themselves in the Balkans, with the result that Bismarck would be left a free hand to turn against France once more. ${ }^{1}$ But it was in vain that Beesly appealed to workmen not to let "the leaders of the so-called Liberal Party trade upon this cry of horror and use it as a means of wriggling back to office."2 They paid little attention to his explanation that "the definitive establishment of the Republic in France will soon tell on the balance of parties here. More than that, it will be the signal for the rise of a new party with a new name, which will before long supersede the worn-out denominations of English Liberalism." 3

It was, however, not the Eastern but the Irish question which proved to be an important forcing-house of new political formations in England. From 1868, when they attempted to form an Irish Friendship Society in London, ${ }^{4}$ until their final break with the Lib-Lab leaders over Gladstone's coercion measures, the Positivists devoted scarcely less attention to this vital matter than Marx himself. Again, their conclusions were much like his, but partly supported by different considerations.

Beesly supported Irish Independence and such measures of "moral coercion" as "boycotting", because all this was good Positivism, and the need for smaller political units had been stressed by his "Master." He was not, however, such a sectarian as to put his case in these terms to his working-class audience. On the contrary, he tried to show that, whether regarded as a moral obligation or as a matter of self-interest, English trade unionists ought to support independence

1 Beesly, E. S., Lord Beaconsfield at the Bar, in: The Bee-Hive, I 8 Sept. 1870, and Impending Dangers, in: The Industrial Review, 28 Apr. 1877.

2 Beesly, E. S., Lord Beaconsfield at the Bar, in: The Bee-Hive, i 8 Sept. 1876.

3 Beesly, E. S., George Odger and French Workmen, in: The Weekly Dispatch, 22 July 1877.

$₫$ R. Congreve to H. Edger, 27 Febr. 1868. (Congreve Collection, Wadham College, Oxford.) 
for Ireland and the actions of the Land League, which was only a trade union under another form. (Between a refusal to work for inadequate wages and a refusal to pay any but fair rents, he saw a perfect equivalence.)

Beesly appealed to English workmen to support the Irish because a blow struck against landlordism in Ireland and the established church in Ireland, could not fail to check the power of this class and this institution at home. Further, so long as the Irish Question was not settled, governments would always have a handy pretext for postponing measures to deal with distress in England. Finally, Irishmen would continue to come to England in search of employment and so help to depress the level of wages. ${ }^{1}$

All these points were made at one time or another by Marx himself. No doubt he objected to Beesly's recommending in $188 \mathrm{I}$ that the Irish garrison ought to be strengthened so as to discourage futile attempts at insurrection, ${ }^{2}$ but this, seen in the context of Beesly's general approach, ought to have been regarded as a matter of secondary importance. The fundamental difference between Marx and Beesly on the Irish question was that the former saw the end of British rule in Ireland as the essential condition for the progress of socialism in England, ${ }^{3}$ whereas Beesly maintained, as an opponent of socialism, that it was the preservation of this rule which was making us "socialists against the grain." (Beesly argued that it was only possible to maintain British dominance in Ireland by permitting the state to control and regulate economic relations, thus establishing a precedent which could be followed in England.) ${ }^{4}$

It was principally on the Irish question that Beesly, Crompton and Congreve wrote in the Labour Standard. Engels was among the contributors to that journal, and it was in its pages that he attempted to indicate the basis for an independent workers' party in England. It must not be overlooked that the Positivists were writing to the same general effect on this matter as well: "The difficulty is, as I have often said, in the way in which the workingmen have allowed themselves to be the supporters of a political party, instead of being independent and their own party - the Labour Party." 5 It was such considerations as these which led Beesly to participate with H. M.

1 Beesly, E. S., Our Foreign and Irish Policy, in: The Fortnightly Review, Febr. 1881 : and a series of articles in The Labour Standard, particularly from 8 Oct. I88 to 20 May I882.

2 Ibid.

3 Marx to Engels, ro Dec. 1869. (Sel. Corr. Torr.)

4 Beesly, E. S., Socialist against the Grain, or the Price of Holding Ireland, London 1887.

${ }^{5}$ Crompton, H., Despotism in Ireland, in: The Labour Standard, 22 Oct. $188 \mathrm{I}$. 
Hyndman and others in the preparatory stages of the formation of the Democratic Federation of $\mathrm{I} 88 \mathrm{I}$. It was not for nothing that, on the occasion of Beesly's death, Hyndman referred to him as "our old friend and teacher". 1

\section{VI}

What was the basis of the collaboration between Beesly and Marx? How is one to account for their mutual regard? Can their friendship be explained simply in terms of temperamental affinities and a chance coincidence, or near coincidence, of view upon a number of limited questions?

It would be unfortunate if the foregoing consideration of the particular conditions of their agreement on this or that issue had obscured the deeper identity in their intellectual manner and method. For, despite differences which might fairly be described as "fundamental" Marx and Beesly shared certain assumptions and values which set their interpretations of social and political development far apart from those of their English contemporaries. Their agreement depended, not merely upon certain common elements in two distinct systems of thought, but upon similarities between the structure and purpose of these systems themselves. This amounts to stating that there are important affinities between Positivism and Marxism and that these must be reckoned with if the collaboration between Beesly and Marx is to be fully understood.

This line of argument is open to at least two objections. The first is that Marx tried to make an exception of Beesly. He seemed anxious to persuade himself that the Professor was "a good man fallen among Positivists". He told Beesly, "I regard you as the only Comtist, either in England or France, who deals with historical turning-points (crises) not as a sectarian but as an historian in the best sense of the word". ${ }^{2}$ In short, it can be argued that Marx looked upon Beesly as an incipient Marxist and valued him, not for those qualities that he shared with other Positivists, but for those which distinguished him from them.

The second objection to the view that Positivism was a positive factor in the association between the two men is simply that Marx always adopted a hostile attitude towards Comte. Probably this ought not to be regarded as a very formidable objection since the history of social philosophy provides numerous instances of thinkers who expressed great hostility towards other systems which, in fact, closely

1 Hyndman, H. M., Edward Spencer Beesly, in: Justice, I 5 th July I9Is.

2 Marx to Beesly, I 2 June 1871 . (Sel. Corr. Torr.) 
resembled their own. Comte's attitude towards Saint-Simon, although complicated by the fact of there having been a personal relationship involved, is a case in point.

It cannot be denied that Beesly differed in certain respects from his fellow Positivists. There never yet was a body of able men belonging to some school or sect who did not differ among themselves on some secondary matters or with respect to the emphasis they accorded to one or other article of faith or belief. Thus, Beesly might have insisted on singling out Marx from Engels on the grounds that the former showed a greater degree of emancipation from chauvinistic prejudice. Indeed, Marx' cosmopolitanism was subject to the only qualification which a Positivist could regard as admissable, namely, it was primarily occidental.

As for the distinctive features of Beesly's Positivism: there is no difficulty in stating the difference between his position and that of Congreve and Crompton. He was a latitudinarian and they were sectarians. He held that Positivism must be a School before it could become a Church. They insisted on the need for establishing a system of public worship in which they would practice the devotional and liturgical forms of the Religion of Humanity. Beesly thought that this would be neither wise nor expedient and it was partly on this issue that the English Positivist body divided in $1878-79 .^{1}$ Beesly would never allow that Comte's life as a whole was exemplary nor that the "Master" was infallible. ${ }^{2}$ However, he certainly thought of himself as a "complete" Positivist. Unlike John Stuart Mill, he would never allow that it was necessary to make a fundamental distinction between Comte's "first" and "second" careers. ${ }^{3} \mathrm{He}$ insisted upon what John Bridges termed "the unity of Comte's life and doctrine" 4 and saw the plan of social reconstruction and the principal of a new secular religion as the necessary outcome of the French philosopher's work. Therefore his differences with Congreve and Crompton never led to a collision on questions of public policy. All three men wrote to the same effect in the Labour Standard in the early eighties when they were trying to make trade unionists take a stand independently of the Liberal Party.

On the question of whether Positivism should be a school or a

1 McGee, J. E. A Crusade for Humanity, London I931, PP. I03-II 2. (This account of the schism neglects some fundamental factors.)

${ }^{2}$ Beesly, E. S., Comte as a Moral Type, Annual Address, 5 Sept. I885, London 1888.

See also his Positivism and Comte in: The Positivist Review, Febr. I897.

${ }^{3}$ Mill, J. S., Comte and Positivism, London I 865.

4 Bridges, J. H., The Unity of Comte's Life and Doctrine, London 1866. 
Church, Bridges and Harrison were in agreement with Beesly. In so far as there were any differences at all between these three friends they were of character rather than opinion, and in so far as they did extend to differences of opinion it is a matter of some difficulty to state accurately what they were. Both Bridges and Harrison did feel, on occasion, that Beesly expressed himself intemperately and Beesly, for his part, thought that Harrison was inclined to be too diplomatic. ${ }^{1}$ Beesly was certainly more continuously and exclusively concerned with working-class affairs than any other Positivist and his attitude towards the working class and the class struggle reflected, to some extent, this deeper commitment.

All Positivists subscribed to the view that the test by which to determine whether any political or social action was right or wrong was whether or not it was in accordance with the interests of the working class. They also held, in a manner rather reminiscent of Saint-Simon, that the working class was not, properly speaking, a class at all, but "the whole body of society" of which other classes were but special organs. The capitalist class had to be moralised until it learnt to look upon its own position in this light. Plainly, this doctrine is ultimately one which teaches "class collaboration," but it leaves open the possibility of a legitimate struggle by workmen against "non-workmen" in the transition period. Comte expected such struggles and even envisaged a limited period in which dictatorial powers would be wielded by a great proletarian governor. It might plausibly be suggested that Beesly distinguished himself from the other Positivists by according a special emphasis to this part of Comte's doctrine; by insisting on the great distance capitalists would have to travel before being "moralised" and, consequently, on the legitimacy of the workmen's struggle with their employers. No doubt, it was the stress which he laid on these considerations which helps to explain the fact that Beesly always admired and respected Marx whereas Frederic Harrison in his old age referred to the German as "an iconoclastic and a fool."2 But it would be a mistake to make too much of all this. The difference, such as it was, concerned emphasis and style. It must be remembered that Bridges was associated with Beesly's remarkable project for an independent workers' party in 1867 ; that Harrison and the others also

1 “The 'subordination of Politics to Morality' demands from Positivist writers an entire abstinence from rotten egg throwing and the amenities of the hustings. And this I don't think Beesly quite sees. He is more advanced in Positive Polity than in Positive Ethics." Bridges to Harrison, cited in Liveing, S., A Nineteenth Century Teacher, London 1926, p. 121 .

2 Harrison, A., Frederic Harrison, London I 926, p. I so. 
defended the Commune; and that organized Positivism as a whole excercised a formative influence upon English socialism. Thus, one must conclude that although Beesly's Positivism did have a special quality and tone which contributed to his friendship with Marx this was of subsidiary importance.

The conclusion that Beesly's Positivism was of primary significance for his friendly relations with Marx is, however, still open to the prima facie objection that it is improbable and paradoxical in view of Marx' hostility towards Comte. This objection can be dealt with by enquiring into the source and extent of that hostility.

It should be noted that while Marx had hardly a good word to say for the "founder" of sociology, he devoted very little attention to him and never troubled to make a detailed critique of Positivism. Moreover, this relative indifference tempered by hostility admits of a very simple explanation. Comte was not a socialist. There is no way of making him into one short of adopting a Sombartian definition of capitalism ${ }^{1}$ and a Morrisonian definition of socialism: - "the assertion of social responsibility for matters which are properly of social concern". ${ }^{2}$ Engels was surely expressing the basic "Marxist" complaint against Comte when he charged Positivism with going in for a compromise to make wages labour tolerable. ${ }^{3} \mathrm{He}$ did, indeed, conceed that there were some brilliant ideas in Comte, but he expressed his suspicion that they all derived from Saint-Simon. ${ }^{4}$ This, one supposes, must have been Marx' opinion. Comte would equal "utopian socialism" arriving post festum: the brilliant premonitions of a new society having been replaced by a grotesque parody on medieval catholicism; a parody which was supported by "systematic pedantry" and by "fanatical and superstitious belief in the miraculous effects of... social science."

This explanation of Marx' attitude towards Comte is apparently too simple to satisfy the few scholars who have troubled to discuss the matter. They notice that Marx seems to have had but a slight acquaintance with Comte's work and conclude that his opposition to Positivism must be related to what they describe as his poor opinion of

1 Sombart tried to define capitalism and to discuss its origins in terms of states of mind. See: Der Moderne Kapitalismus, 1928, Ed. 1, p. 25. Cited and discussed by Dobb, M., Studies in the Development of Capitalism, London 1946, p. 5.

2 Mr. Herbert Morrison, in a letter to the present writer dated I7 June I958, confirms that he has used this definition in "a number of speeches."

3 Minutes of the General Council, 3 I Jan. I 87 I. (I.I.S.H.)

4 Engels to F. Tennies, 24 Jan. I 895 . (Sel. Corr. 1956.)

${ }^{5}$ Marx and Engels, The Communist Manifesto, London 1948, Part iii, section iii: "Critical-utopian socialism and communism." 
the Positivists. Lucy Prenant suggests that it was English Positivists who were to blame, ${ }^{1}$ while Bottomore and Rubel lay the blame at the door of the French. After incorrectly asserting that Marx was impressed by the encyclopaedic character of Comte's work, they go on to suggest that Marx' low estimate of Comte must be related to his hostility "to the positivists who wished to impose a particular philosophic doctrine upon the labour movement." This, they allege, "brings into relief his own repudiation of philosophical speculations upon the course of history, and his rejection of ideologies, even [sic] in the form of a new 'positivist' religion."2

Even when due allowance has been made for the fact that Bottomore and Rubel have wisely placed their main emphasis upon Marx' opposition to the French disciples of Comte, this argument is far from convincing. Indeed, one gains a real insight into the friendship of Beesly and Marx if one simply reverses their argument. It was Marx' unfavourable estimate of Comte which told against his regard for Beesly and not vice versa. It was the presence of the "historicist" element in the thinking of both men which facilitated their collaboration; Marx' hostility to Comte being due, not to the French philosopher's method - apart from its intellectualism - but to the nonsocialist conclusions of his special sort of "historicism." The German socialist might protest against Beesly's Positivism, but upon examination it was the affinities between Beesly's Positivism - in which the class struggle and the sense of the "historic destiny" of the proletariat are given a new edge and definition - and Marx' own position, which furnished the foundation of their association. In short, when Marx protested against Beesly's Comtism, he ignored the fact that this was also a condition which made for their collaboration. When he abused Comte, he over-looked the fact that the Frenchman was trying to do much the same thing as he was and that he was using much the same materials.

Comte, like Marx, drew heavily upon classical German philosophy; French Socialism and, in particular, Saint-Simon; and upon Adam Smith, if not upon English Political Economy as a whole. Out of these materials both men attempted to fashion a new science of society.

1 Prenant, Lucy, Karl Marx et Auguste Comte, in: A la lumière du Marxisme, Tome II (Paris 1937), p. 26.

2 Bottomore, T. B. and Rubel, M., Karl Marx, Selected writings in sociology and social philosophy, London 1956, pp. 13-14. - In his letter to Engels of 25 th July 1866 Marx explained that it was Comte's "encyclopaedic touch" which impressed the English and French. He does not suggest that this impressed him. On the contrary, he refers to "this Positivist rot." (Sel. Corr. Torr.) 
Neither of them could conceive of this science except in historical terms and as resting upon "historical laws." Comte imagined that this achievement would make it possible to place politics and morals upon a scientific basis; put an end to the divorce between science and the affirmations of our moral experience by giving point to facts and ground to values; and to finally close an era of restless competition in economic and in intelectual life which left us secure neither in our possesions nor in our beliefs. It is arguable that Marx thought in very similar terms, but that he expressed himself more cautiously and less explicitly. ${ }^{1}$

What E. H. Carr said of Condorcet can certainly be applied to Comte; he exchanged the consolations of theology for those of history. ${ }^{2}$ Theology seemed irreconcilable with science. Moreover, its subject matter had undergone a change. It had turned its back on enquiries into the nature of God and concern with apocalyptic forecasts; it had largely discarded these preoccupations in favour of a new interest in the fate of the individual soul in relation to God. Comte tried to make his new historical science fill the vacuum left by theology. He discovered a "real" or "human" providence according to which men made their own history, but under conditions determined independently of their will. He restored the apocalyptic under another form and once again set the chosen people off on their trek to the promised land. All the materials for the same story are to be found in Marx. Some of his followers have either avowedly or implicitly constructed them into a secular religion. ${ }^{3}$

1 This is not the place for a detailed discussion of Professor Popper's critique of Marx' "historicism," "Scientism," "Holism" etc. (Popper, K.R., The Open Society and Its Enemies [two volumes], London 1945, and The Poverty of Historicism, London 1957). Popper encourages a rather sweeping assimilation of Marx' ideas to those of Comte and others. This line of argument has been taken up and popularised by several other distinguished authorities. (See, for example, Acton, H.B., The Illusion of the Epoch, London 1956; Berlin, I., Historical Inevitability, being the Auguste Comte Memorial Trust Lecture, No I, London 1954; Von Hayek, E.A., The Counter-Revolution of Science, Illinois, 1952.) The fact of Beesly's collaboration with Marx lends some indirect support to the contention made in all these works that Positivism and Marxism belong to the same genus. It has, of course, no bearing whatsoever on the truth or falsity of Professor Popper's conclusions respecting the falacious and obnoxious character of Marx' method. Nor does it justify the practice, favoured by some of these writers, of building up selections from Hegel, Comte, Marx, Mill, and others, into a composite body of doctrine, an "Aunt Sally," which can be knocked down to the accompaniment of loud announcements concerning the "refutation" of Marx.

2 Carr, E. H., The New Society, London 1951, p. 2.

${ }^{3}$ An explicit suggestion of how this might be done was made by Joseph Dietzgen (The Religion of Socialism, being pp. 90-1 54 in Philosophical Essays, Chicago 1914). The result is strikingly reminiscent of Comte's Religion of Humanity. Beatrice Webb sensed the secular religious quality of organized Marxism and expressly compared it with Positivism: 
In 1848 , Comte, as well as Marx, discussed the conditions of the transition to the new society and the part to be played by the proletariat in effecting the change. For Marx, this involved the organization of the proletariat into a class; for Comte, it meant its organization into a new universal church. It has been correctly observed that Comte, despite a glimmering of the truth, made the error of not understanding "that the new religion would not be metaphysical but political"."

It is unnecessary to look further for the basis of Beesly's association with Marx. He was a Positivist and, accordingly, he was as impressed as Marx was by the impersonal force of historical change. Hence their common contempt for political or philanthropic nostrums which took no account of the tendencies of historical development. It was because Beesly was a Positivist that he saw the political potentialities - as well as the sufferings - of the proletariat and could join with Marx and Engels in urging workmen to be their own independent party or in the defence of the Paris Commune. It was because Beesly was a Positivist that he could share Marx' contempt for the moral and intellectual complacency of the bourgeoisie and declare himself averse to individual liberty when it merely served as a pretext for capitalist oppression. Positivism also explains the close proximity of Beesly's social ideals to those of Marx; wealth which was social in its origins should be used in socially beneficial ways and not simply in accordance with the whims of the property owning classes. Competition should give place to central planning and control. The difference between the two men turned on how these ends were to be attained;

"It is the invention of the religious order, as the determining factor in the life of a great nation, that is the magnet which attracts me to Russia. Practically, that religion is Comteism - the religion of Humanity. Auguste Comte comes to his own. Whether he would recognise this strange resurrection of his idea I very much doubt." (Cole, M. [Editor], Beatrice Webb Diaries, 1924-32, London 1956, p. 299).

The allegedly religious aspect of Marxism, whether considered as a body of ideas or an organized movement, has been widely canvassed. Perhaps the best short statement of the argument is to be found in Reinhold Niebuhr's "Christian Politics and Communist Religion" being Chapter III of Part III of Christianity and the Social Revolution, edited by John Lewis, London 1937. Among the other more significant contributions to this topic see Michels, R., Political Parties; a Sociological Study of the Oligarchical Tendencies of Modern Democracy, Illinois 1949; Russell, B., The Practice and Theory of Bolshevism, London 1920; Keynes, J. M., What is the Communist Faith?, being Part One of A Short View of Russia, reprinted in: Essays in Persuasion, London 1931, pp. 297-305. Hitherto there has been no attempt to inform this discussion by enquiring into the relationship between Marxism and the rise, in the early nineteenth century, of the first secular religions in the West. It is proposed to make this the subject of a future article. 1 Duverger, M., Political Parties: Their Organisation and Activity in the Modern State, first English edition, London I954, P. 123. 
in Beesly's view, by the slow growth of a common intellectual and moral authority; in Marx' view, only by creating a community of interests through the over-throw of existing property relations.

It was because Beesly was a Positivist that he shared with Marx a highly critical view of liberal and Parliamentary Democracy. He saw in parliamentary institutions and the unquestioned acceptance of majority rule a metaphysical principle which, when applied in practice, invariably served the selfish interests of the middle class.

No release from this conclusion can be found by pointing out that Beesly was a liberal. For he was a liberal only in the formal sense of one who is frequently found voting for and acting with a particular party of that name. He once contributed a few passages to a volume entitled "Why I am a Liberal." In his remarks he made it clear that if he acted with the Liberals it was because "there was nothing else for it" and he expressly stated that his politics were based upon a philosophical position which was far removed from that of most members of the party. ${ }^{1} \mathrm{He}$ was continually, although unjustly, charged with being a socialist. ${ }^{2}$ In 1897 he resigned from the central and local liberal associations to which he had belonged because of his dissatisfaction with their failure to resist imperialism ${ }^{3}$ and three years later he advised readers of the Positivist Review to vote for the social-democrats. ${ }^{4} \mathrm{He}$ welcomed the formation of the Parliamentary Labour Party in 1906, not in the hope that it would supersede the Liberals, but in the expectation that it would preserve its independence and serve as the conscience of the House of Commons on colonial questions. ${ }^{5}$

It is fully in accord with our interpretation of the relations between Beesly and Marx that the Positivist should have exerted far more influence upon the development of socialism in Britain than he did upon liberalism. He was the friend and teacher not only of Hyndman and Bax (it is most instructive to follow the course of Bax' conversion from a Positivist sympathiser to a socialist), ${ }^{6}$ but also of Wicksteed and the Labour Church movement, ${ }^{7}$ and, in conjunction with many of

1 Reid, A. (Editor), Why I am a Liberal, London n.d. [1885 ?], p. 21.

${ }^{2}$ For example, "Professor Beesley [sic], one of the most energetic leaders of the socialistic movement in London, is a Positivist." Bagenal, P. H., The International and its influence on English Politics, in: The National Review, Vol I I, pp. 422-423.

3 Beesly, E. S., Paragraphs, in: The Positivist Review, Sept. 1897.

4 Beesly, E. S., The Khaki Election, in: The Positivist Review, Oct. 1900.

${ }^{5}$ Beesly, E. S., Liberals and Labour, in: The Positivist Review, Nov, 1906.

${ }^{6}$ Bax, E. B., Letter to the Echo, 2 July 1878 ; an article in Modern Thought, Aug. 1879; and his The Religion of Socialism, London n.d. [1887?], pp. 52-53.

${ }^{7}$ Herford, C. H., P. H. Wicksteed: His Life and Work, London I 93 I, Pp. 33-44 and p. 79. 
his fellow Positivists, of a number of leading Fabians. Sydney Olivier, ${ }^{1}$ Annie Besant, ${ }^{2}$ Sydney and Beatrice Webb all came under Positivist influence and Sydney Webb even went to the length of reading a very sympathetic paper on the economics of a Positivist community to a meeting of the Fabian Society. ${ }^{3}$

Beesly always thought of socialism as a useful preparatory school for Positivism.4 When events began to suggest that the actual relationship was the inverse of this, he did not cease to show his fraternal feelings towards socialists; particularly towards militant ones. He confessed to a strong liking for them personally and he declared that they seemed to be the only people capable of dealing with jingoism. ${ }^{5}$ As in the days of his friendship with Marx, Beesly saw in "the stern resolve of a classconscious proletariat" the most effective answer to militarism. It was appropriate that the last lines he ever wrote were a defence of the honour of Karl Liebknecht and those German socialists who dared to oppose the war. ${ }^{6}$

In the labour movement of the eighteen-sixties and seventies, Marx and Beesly stood out together as exponents of theory and principle in the midst of boundless empiricism. In an age of compromise they distinguished themselves by their fanaticism. Beesly acknowledged that Karl Marx was a "great spirit" 7 and Marx, for his part, would not have denied Beesly's right to the epitaph of the dying Hazlett: "I have written not a line that licks the dust". ${ }^{8}$

1 Olivier, M., Letters and Selected Writings of Sydney Olivier, London 1948, pp. 55-64. 2 Besant, A., Auguste Comte - His Philosophy, His Religion, His Sociology, London n.d. [1883 ?], pp. I-39.

s Webb, S., The Economics of a Positivist Community. Abstract in: The Practical Socialist, Febr. 1886.

4 Beesly, E. S., Positivists and Workmen, in: The Fortnightly Review, July 1875 .

5 Beesly, E. S., Pacifism, in: The Positivist Review, Nov. 1907.

- Beesly, E. S., Paragraph, in: The Positivist Review, Jan. I915.

7 Beer, M., Fifty Years of International Socialism, London 1935, p. 135 .

8 The Manchester Guardian, Io July 1915, in its obituary notice on Beesly, "Death of a Great Positivist," applied Hazlett's words to him. 